\title{
ETIOLOGY OF ACUTE DIARRHEA AMONG CHILDREN IN RIBEIRÃO PRETO-SP, BRAZIL
}

\begin{abstract}
SUMMARY
To study the main enteropathogens causing diarrhea in the region of Ribeirão Preto regarding serogroups and serotypes, the feces of 1836 children under 10 years old, from both sexes, attack of acute gastroenteritis, were analysed during a period of 4 years in Adolfo Lutz Institute - Ribeirão Preto, SP. The pathogens identified by standard methods were the following: Escherichia coli, Salmonella spp., Shigella spp., Campylobacter spp., Yersinia spp., and Cryptosporidium spp. Positive samples were 22.8\% (419) with $1.7 \%$ association of pathogens. Larger isolates were mainly from children 0 to 11 months old. Enteropathogenic $E$. coli (EPEC) was most frequent $(8.7 \%)$ with predominance of serogroup $\mathrm{O} 119$ (40.2\%), followed by Shigella (6.2\%), 63.6\% of which S. sonnei.
\end{abstract}

KEYWORDS: Enteropathogens; Diarrhea; Children.

\section{INTRODUCTION}

Several factors can contribute to intestinal infections: duration of maternal breast feeding, food and enviromental contaminations ${ }^{18,30}$, maternal education and employment, home location, family income, infant's birth weight ${ }^{27}$, access to treated water and basic sanitary conditions $^{18,32}$, seasonal variations and in special, the age of the host $\mathrm{t}^{11}$.

The morbidity of the infectious diseases associated with malnutrition is one of the main causes of delayed physical growth in children ${ }^{27}$. In Asia (excluding China), Africa and Latin America 4.6 to 6 milllion children under five years old die of diarrhea each year ${ }^{15}$. In Ethiopia in 1993 , nearly $25 \%$ of deaths in this age bracket were due to diarrhea ${ }^{27}$.

To prevent dehydration and death, children are admitted to hospitals in underdeveloped countries ${ }^{5,10}$, not only increasing costs to society but also aggravating a public health problem by being communicators and transmiters in hospital infections ${ }^{25}$. Thus, knowledge of the etiology of acute diarrhea is of great importance for the control and prevention of disease.

Bacterial agents that most commonly cause diarrhea in Brazil are: enteropathogenic Escherichia coli (EPEC), enterotoxigenic E. coli (ETEC), Shigella spp., Salmonella spp., and Campylobacter spp s,11,30. $^{2}$

This study was conducted to investigate the frequency and etiology of diarrhea in children admitted in hospitals or outpatient clinics in the region of Ribeirão Preto- SP, characterizing the enteropathogens isolated interms of serogroups and serotypes.

\section{MATERIALS AND METHODS}

Subjects: From January 1994 to December 1997, were investigated enteropathogens agents in 946 children of outpatient clinics and 890 of patients admitted to pediatric hospitals, all under ten years old, with diarrhea. Routine diagnostic tests on stool samples included culture for enteropathogenic Escherichia coli (EPEC), enteroinvasive (EIEC), enterohemorrhagic Escherichia coli O157:H7 (EHEC), Salmonella spp., Shigella spp., Campylobacter spp. and Yersinia enterocolitica. In selected cases special tests for Cryptosporidium spp. were also performed.

Collection of specimens: Coprocultures were made from feces transported at room temperature in a Cary Blair medium ${ }^{9}$. Cryptosporidium spp., were made from feces kept in refrigeration until taken to the laboratory of the Adolfo Lutz Institute (IAL) in Ribeirão Preto-SP.

Bacteriologic studies: The isolation and presumptive identification of EPEC, EIEC, Salmonella spp., and Shigella spp. were performed according to the method described previously22 ${ }^{22}$ EHEC 0157:H7 was studied in a MacConkey medium containing sorbitol ${ }^{9}$. Biochemical characterization was made by the method of EDWARDS \& EWING ${ }^{7}$. The serotypes of samples of Shigella ${ }^{7}$ and Salmonella ${ }^{23}$ were determined in the laboratories of IAL (main branch) in São Paulo. Yersinia enterocolitica was isolated and identified biochemically by the methods of respectively, GRAY ${ }^{13}$ and FARMER \& KELLY'; serotyping and phagetyping were performed in the laboratory of "Universidade Estadual Paulista" (UNESP) in the city of Araraquara (reference laboratory) ${ }^{20,33}$. The isolation and identification of Campylobacter spp. was made 
according to MORRIS \& PATTON ${ }^{19}$, MAGALHÃES \& ANDRADE $^{17}$ and SKIRROW \& BENJAMIN ${ }^{28}$.

Cryptosporidium spp.: Was detected from concentrated formalinfixed stool samples by the modified Kinyoun method, based on the acidresistance of the protozoon, described by SMITH \& BARLETT ${ }^{29}$.

\section{RESULTS}

One or more enteropathogens were identified in 419 samples $(22.8 \%)$ of the 1836 studied. This total, $388(21.1 \%)$ were positive for only one microrganism, in $31(1.7 \%)$ cases mixed infections occurred, 30 with associated of the two enteropathogens and one with three. EPEC and Campylobacter spp. were the enteropathogens most commonly associated with other microorganisms. EHEC O157:H7 was not detected.

The table 1 summarizes: the frequency of enteropathogens isolated from single or multiple infections. The prevailing EPEC serogroups were O119 (40.2\%), O128 (15.7\%), O111(11.3\%), O26 (10\%), O55 (8.8\%) and other serogroups. The most frequent Shigella serotype was sonnei
(63.16\%), among samples of Shigella flexneri, the type 2 was the most common. Campylobacter spp. was the third most frequent $(5.4 \%)$ organism isolated, with predominance of $C$. jejuni. There were 12 Salmonella serotypes with predominance of $S$. Enteritidis $(36.6 \%)$, followed by $S$. I 4,5,12:i:-, $S$. Braendenburg, $S$. Infantis, $S$. Mbandaka, $S$. Agona, $S$. Indiana, $S$. Braenderup, $S$. Javiana, $S$. Give, $S$. Worthington and $S$. Typhimurium. The isolated EIEC belonged to serogroups O167, O143 and O124. Yersinia was characterized as Y. enterocolitica 4-O:3VIII .

Of the 451 enteropathogens isolated, including mixed infections (Table 1), 51.7\% were from the group of children with ages between 0 and 11 months for pathogens in general, but EPEC was the most frequent one in this age group (Table 2).

The Figure 1 shows the distribution of cases according to the origin of the samples. Of $890(48.4 \%)$ samples from children admitted to hospitals, $207(23.3 \%)$ were identified enteropathogens, while 946 $(51.5 \%)$ samples from outpatient clinics were positive in $244(25.8 \%)$ of the cases.

Table 1

Prevalence of enteropathogens in the stools of 1836 infants with diarrhea, Ribeirão Preto, SP, Brazil, 1994-1997

\begin{tabular}{|c|c|c|c|c|c|c|c|c|c|c|}
\hline \multirow[t]{2}{*}{ Enteropathogens* } & \multicolumn{2}{|c|}{$\begin{array}{c}1994 \\
n=824\end{array}$} & \multicolumn{2}{|c|}{$\begin{array}{c}1995 \\
n=557\end{array}$} & \multicolumn{2}{|c|}{$\begin{array}{c}1996 \\
n=307\end{array}$} & \multicolumn{2}{|c|}{$\begin{array}{c}1997 \\
n=148\end{array}$} & \multicolumn{2}{|c|}{$\begin{array}{l}\text { TOTAL } \\
\mathrm{n}=1836\end{array}$} \\
\hline & $\mathrm{N}$ & $\%$ & $\mathrm{~N}$ & $\%$ & $\mathrm{~N}$ & $\%$ & $\mathrm{~N}$ & $\%$ & $\mathrm{~N}$ & $\%$ \\
\hline EPEC & 81 & 9.8 & 45 & 8.1 & 21 & 6.8 & 12 & 8.1 & 159 & 8.7 \\
\hline Shigella spp. & 45 & 5.5 & 47 & 8.4 & 18 & 5.9 & 04 & 2.7 & 114 & 6.2 \\
\hline Campylobacter spp. & 45 & 5.5 & 39 & 7.0 & 12 & 3.9 & 03 & 2.0 & 99 & 5.4 \\
\hline Salmonella spp. & 12 & 1.4 & 19 & 3.4 & 07 & 2.3 & 03 & 2.0 & 41 & 2.2 \\
\hline Cryptosporidium spp. & 22 & 2.7 & 08 & 1.4 & 04 & 1.3 & - & - & 34 & 1.8 \\
\hline EIEC & 02 & 0.2 & - & - & - & - & 01 & 0.7 & 03 & 0.2 \\
\hline Yersinia spp. & - & - & - & - & - & - & 01 & 0.7 & 01 & 0.05 \\
\hline Total & 207 & 25.1 & 158 & 28.4 & 62 & 20.2 & 24 & 16.2 & 451 & 24.6 \\
\hline
\end{tabular}

NOTE: EPEC = enteropathogenic Escherichia coli. EIEC = enteroinvasive Escherichia coli.; $*$ Escherichia coli O157:H7 were not detected

Table2

Distribution of 451 enteropathogens from diarrhea children's feces, according to age, in Ribeirão Preto, SP, Brazil, 1994-1997

\begin{tabular}{|c|c|c|c|c|c|c|c|c|c|c|c|c|c|c|}
\hline \multirow{3}{*}{ Enteropathogens (N) } & \multicolumn{14}{|c|}{ Ages } \\
\hline & \multicolumn{2}{|c|}{$0-11 \mathrm{~m}$} & \multicolumn{2}{|c|}{$1-2 y$} & \multicolumn{2}{|c|}{$2-4 y$} & \multicolumn{2}{|c|}{$4-6 y$} & \multicolumn{2}{|c|}{$6-8 y$} & \multicolumn{2}{|c|}{$8-10 y$} & \multicolumn{2}{|c|}{ NI } \\
\hline & $\mathrm{N}$ & $(\%)$ & $\mathrm{N}$ & $(\%)$ & $\mathrm{N}$ & $(\%)$ & $\mathrm{N}$ & $(\%)$ & $\mathrm{N}$ & $(\%)$ & $\mathrm{N}$ & $(\%)$ & $\mathrm{N}^{\circ}$ & $(\%)$ \\
\hline EPEC (159) & 121 & $(76.1)$ & 19 & $(11.9)$ & 07 & $(4.4)$ & 03 & $(1.9)$ & 03 & (1.9) & 02 & $(1.3)$ & 04 & $(2.5)$ \\
\hline Shigella spp.(114) & 28 & $(24.6)$ & 18 & $(15.8)$ & 27 & $(23.7)$ & 17 & $(14.9)$ & 07 & $(6.1)$ & 10 & $(8.8)$ & 07 & $(6.1)$ \\
\hline Campylobacter spp. (99) & 47 & $(47.5)$ & 27 & $(27.3)$ & 15 & $(15.1)$ & 01 & $(1.0)$ & - & - & 02 & $(2.0)$ & 07 & $(7.1)$ \\
\hline Salmonella spp. (41) & 20 & $(48.8)$ & 12 & $(29.3)$ & 03 & $(7.3)$ & 03 & $(7.3)$ & 01 & (2.4) & 02 & $(4.9)$ & - & - \\
\hline Cryptosporidium spp.(34) & 15 & $(44.1)$ & 15 & $(44.1)$ & 02 & $(5.9)$ & - & - & - & - & - & - & 02 & $(5.9)$ \\
\hline EIEC (03) & 02 & $(66.7)$ & - & - & - & - & - & - & - & - & 01 & $(33.3)$ & - & - \\
\hline Yersinia enterocolitica $(01)$ & - & - & - & - & 01 & $(100.0)$ & - & - & - & - & - & - & - & - \\
\hline TOTAL (451) & 233 & $(51.7)$ & 91 & $(20.2)$ & 55 & $(12.2)$ & 24 & $(5.3)$ & 11 & $(2.4)$ & 17 & $(3.8)$ & 20 & $(4.4)$ \\
\hline
\end{tabular}

$\%$ relative to the number of samples of each enteropathogen; NI: no information of age 


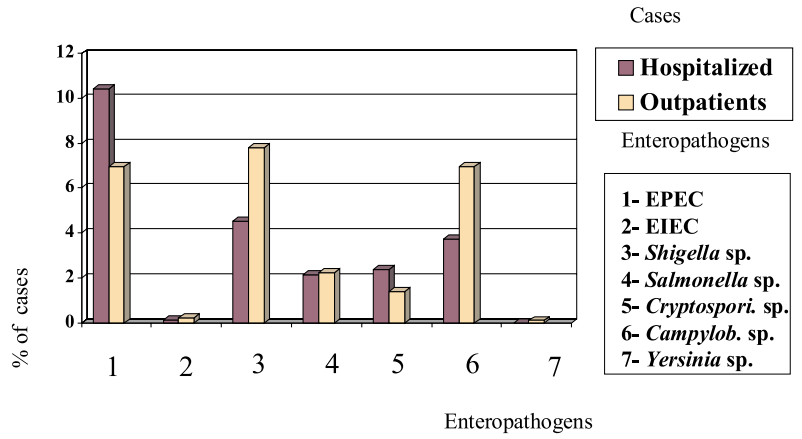

Fig. 1 - Percentages (\%) of enteropathogens isolated from hospitalized and outpatients children attended in the region of Ribeirão Preto from 1994 to 1997.

\section{DISCUSSION}

The results found in the present study are similar to those reported from other places in Brazil ${ }^{12,30}$ and other countries ${ }^{1,21}$, where EPEC constitutes one of the most important etiological agents of acute diarrhea. Among enteropathogens isolated, EPEC stood out by its presence in $8.7 \%$ of the cases, including mixed infections. GOMES et al. $(1991)^{11}$, isolated EPEC in $26 \%$ of the cases of infantile diarrhea. In Argentina ${ }^{21}$ was found approximately 3 times greater percentage of EPEC (25.2\%), compared to that reported in the present study $(8.7 \%)$.

Our studies were restricted to EPEC serogroups identification, however the EPEC serogroups are very heterogeneous. There is extensive variation in virulence among bacterial strains demonstrating that identification of EPEC by serotype is very important ${ }^{11,12}$.

The figure 1 shows that the majority of the enteropathogens were from the outpatients less EPEC and Cryptosporidium spp. 10.4\% of the strains of EPEC were isolated from hospitalized children; this is a reason for concern from the epidemiological viewpoint, since these children represent an important reservoir of these microorganisms, capable of constituting a source of hospital infection ${ }^{11,32}$.

The second most frequent etiological agent isolated, was Shigella spp. the most frequent pathogen in children over two years old. Similar data were found by HUILAN et al. ${ }^{16}$; they are explainable by the small infecting innoculum required to start this infection, as well as by the increased contact between children of this age range, mainly in day nurseries ${ }^{14,18}$. Shigella sonnei appeared more frequently than S. flexneri in contrast to results of other authors in Brazil ${ }^{11,31}$ and Argentina ${ }^{21}$, who report that S. flexneri is the most prevalent species isolated. Among samples of S. flexneri, the type 2 was the most common, in agreement with findings by other authors ${ }^{2,21}$.

Campylobacter spp. was the third enteropathogen found in our study, being more frequent than Salmonella spp. as the cause of enteritis. Its importance as a cause of diarrhea has been emphasized in Brazil ${ }^{11,30}$, and other countries ${ }^{16,26}$.

Was noted a predominance of the serotype Enteritidis (36.6\%), in infections by the genus Salmonella, including mixed ones. Other authors
${ }^{2,8}$, observed an increase of this serotype in the last decade. According to EIGUER et al. ${ }^{8}$, this serotype has been one of the major causes of alimentary toxinfection in man.

Considering the increasing importance of Cryptosporidium spp. in infantile diarrhea, the prevalence of this agent in our region was investigated; a frequency of $1.8 \%$ was found, mixed infections included. Other studies in Ribeirão Preto, showed higher values $\left(13.2 \%{ }^{3}\right.$, and $27 \%^{24}$ ). The necessity of the routine investigation in this aspect is therefore noticed.

EHEC was not found in the present study, in agreement with reports by GOMES et al. ${ }^{11}$. Unlike results of authors which could not isolate this etiologic agent ${ }^{21,26}$. In the present study was isolated one sample of Yersinia spp., similar to that found in São Paulo by TORRES et al. ${ }^{30}$.

The age group most affected by EPEC was that of children less than 2 years old, with marked prevalence of ages 0-11 months, and decreasing with age, as previously reported ${ }^{1}$. The greatest incidence of Campylobacter spp. occurred in children between 0 and 4 years, in disagreement with SKIRROW \& BENJAMIN ${ }^{28}$, who reported a predominance of this infection in older children and young adults. Cryptosporidium spp. is an opportunist parasite, infection is more common in children than adults because the host becomes more resistant with aging ${ }^{24}$. This was confirmed in the present work, because the parasite was more frequent in children less than 2 years old, practically disappearing after 4 years, as also related by DIAS et al. ${ }^{6}$. In disagreement with earlier cited authors, BICHARA et al. ${ }^{4}$, found Cryptosporidium spp. in students 11 to 14 years old, demonstrating than besides immunity, sanitary hygiene and contact with animals are also important.

\section{CONCLUSIONS}

Enteropathogens EPEC, Shigella spp. and Cryptosporidium spp. were the most frequently found causes of diarrhea in children under ten years old in the region of Ribeirão Preto, with the serotype O119 of EPEC, $S$. sonnei and $C$. jejuni being the most isolated ones. Among positive cases, approximately $84 \%$ occurred in children under four years old and $52 \%$ between ages 0 and 11 months.

\section{RESUMO}

\section{Principais enteropatógenos causadores de diarréia em crianças, na região de Ribeirão Preto-SP, Brasil}

Com o objetivo de caracterizar os principais enteropatógenos causadores de diarréia na região de Ribeirão Preto, quanto aos sorogrupos e sorotipos, por um período de 4 anos foram estudadas fezes de 1836 crianças, menores de 10 anos de idade, de ambos os sexos, portadoras de gastrenterite aguda no IAL de Ribeirão Preto, SP. Foram pesquisados os seguintes enteropatógenos: Escherichia coli, Salmonella sp., Shigella sp., Campylobacter sp., Yersinia sp., e Cryptosporidium sp., identificados através de metodologia tradicional. Foram positivas $419(22,8 \%)$ amostras, com $1,7 \%$ de associação entre enteropatógenos. Houve predomínio na faixa etária de 0 a 11 meses. Destacou-se a E.coli enteropatogênica (EPEC) $(8,7 \%)$, sendo mais frequente o sorogrupo O119 (40,2\%), seguida do gênero Shigella $(6,2 \%)$, dos quais $63,2 \%$ corresponderam à $S$. sonnei. 


\section{REFERENCES}

1. ALBERT, M.J.; FARUQUE, S.M.; FARUQUE, A.S.G. et al. - Controlled study of Escherichia coli diarrheal infections in Bangladeshi children. J. clin. Microbiol., 33: 973-977, 1995.

2. ALMEIDA, I.A.Z.C.; RODRIGUES, E.C.A.; MARQUES, D.F.; DUARTE, V.L.S. \& GUIMARÃES, E.Q. - Frequência de isolamento de enterobactérias patogênicas na região de São José do Rio Preto-SP. In: REUNIÃO ANUAL DO INSTITUTO ADOLFO LUTZ, 2., São Paulo, 1997. Anais. p. 175

3. ALMEIDA, S.; PINELLI, R.M.; ELIAS, M.L. et al. - Cryptosporidium sp. importância na etiologia da diarréia aguda prolongada do lactente. In: JORNADA PAULISTA DE PARASITOLOGIA, 9., Ribeirão Preto, 1992. Anais. 1992. p. 39.

4. BICHARA, C.C.; BICHARA, C.D.; ROCHA, C.M.F. et al. - Cryptosporidiose: incidência em 500 escolares de 7 a 15 anos pela técnica de Ziehl Neelsen modificada em uma escola pública da periferia de Belém- PA. Rev. Soc. bras. Med. trop., 27: 334, 1994.

5. CLAESON, M. \& MERSON, M.H. - Global progress in the control of diarrheal diseases. Pediat. infect. Dis. J., 9: 345-355, 1990.

6. DIAS, F.A.; ROCHA, M.F.H.; SEARS, C.L.S.; GUERRANT, R.L. \& LIMA, A.A.M. Avaliação clinico-nutricional de cryptosporidiose em crianças de uma comunidade urbana em Fortaleza-CE. Rev. Soc. bras. Med. trop., 27: 334, 1994.

7. EDWARDS, P.R. \& EWING, W.H. - Identification of enterobacteriaceae. 4.ed. New York, Elsevier, 1986.

8. EIGUER, T.; CAFFER, M.I. \& FRONCHKOWSKY, G.B. - Importância de la Salmonella Enteriridis en brotes de enfermedades transmitidas por alimentos en Argentina. Años 1986-1988. Rev. argent. Microbiol., 22: 31-36, 1990.

9. FARMER, J.J. \& KELLY, M.T. - Enterobacteriaceae In: BALOWS, A.; HAUSLER,W.J.; HERRMANN, K.L.; INENBERG, H.D. \& SHADOMY, H.J. Manual of clinical microbiology. 5.ed. Washington, American Society for Microbiology, 1991. p.370373

10. FORSBERG, B.C.; SULLESTA, E.; PIECHE, S. \& LAMBO, N. - Costs of diarrhoeal diseases and the savings from a control programme in Ceba, Philippines. Bull. Wld. Hlth. Org., 71: 579-586, 1993.

11. GOMES, T.A.T.; RASSI, V. \& MACDONALD, K.L. - Enteropathogens associated with acute diarrheal disease in urban infants in São Paulo, Brazil. J. infect. Dis., 164: 331-337, 1991

12. GOMES, T.A.T.; GRIFFIN, P.M.; IVEY, C.; TRABULSI, L.R. \& RAMOS, S.R.T.S. EPEC infections in São Paulo. Rev. Microbiol., 27: 25-33, 1996.

13. GRAY. L.D. - Escherichia, Salmonella, Shigella and Yersinia. In: MURRAY, P.R.; BARON, E.J.; PFALLER, M.A.; TENOVER, F.C. \& YOLKEN, R.H. Manual of clinical microbiology. 6.ed. Washington, American Society for Microbiology, 1995. p. $450-456$

14. GUERRANT, R.L. \& BOBAK, D.A. - Bacterial and protozoal gastroenteritis. New Engl. J. Med., 325: 327-340, 1991.

15. GUERRANT, R.L.; HUGHES, J.M.; LIMA, N.L. \& CRANE, J.K. - Diarrhea in developed and developing countries: magnitude, special settings, and etiologies. Rev. infect. Dis., 12(suppl. 1): S41-S50, 1990.

16. HUILAN, S.; ZHEN, L.G.; MATHAN, M.M. et al. - Etiology of acute diarrhoea among children in developing countries: a multicentre study in five countries. Bull. Wld. Hlth. Org., 69: 549-555, 1991.

17. MAGALHÃES, M. \& ANDRADE, M.A. - Simple and inexpensive method for culturing Campylobacter fetus subsp. jejuni. Rev. Microbiol., 13: 124-125, 1982.
18. MOTARJEMI, Y.; KÄFERSTEIN, F.; MOY, G. \& QUEVEDO, F. - Contaminated weaning food: a major risk factor for diarrhoea and associated malnutrition. Bull. Wld. Hlth. Org., 71: 79-92, 1993.

19. MORRIS, G.K. \& PATTON, C.M. - Campylobacter. In: LENNETTE, E.H.; BALOWS, A.; HAUSLER, W.J. \& SHADOMY, H.J. Manual of clinical Microbiology. 4.ed. Washington, American Society for Microbiology, 1985. p. 302-308.

20. NICOLLE, P.; MOLLARET, H.H. \& BRAULT, J. - Nouveaux résultats sur la lysotypie de Yersinia enterocolitica portant sur plus de 4000 souches d'origines diverses. Rev. Epidem. Santé publ., 24: 479-496, 1976.

21. NOTARIO, R.; BORDA, N.; GAMBANDE, T. \& SUTICH, E. - Species and serovars of enteropathogenic agents associated with acute diarrheal disease in Rosario, Argentina Rev. Inst. Med. trop. S. Paulo, 38: 5-7, 1996.

22. PESSÔA, G.V.A.; IRINO, K.; CALZADA, C.T.; MELLES, C.E.A. \& KANO, E.J. Ocorrência de bactérias enteropatogênicas em São Paulo, no septênio 1970-76. I. Sorotipos de Salmonella isolados e identificados. Rev. Inst. Adolfo Lutz, 38: 87105,1978

23. POPOFF, M.Y. \& LE MINOR, L. - Formules antigéniques des sérovars de Salmonella Paris, Centre Collaborateur OMS de Réference et de Recherche pour les Salmonella, Institut Pasteur, 1997.

24. ROCHA, G.M.; FERNANDES, M.A.N. \& FERNANDES, F. - Criptosporidiose em lactentes albergados em creches - Ribeirão Preto-SP. In: JORNADA PAULISTA DE PARASITOLOGIA, 9., Ribeirão Preto, 1992. Anais. p. 40.

25. SABRÁ, A.M.C. - Diarréias na infância. 2.ed. Rio de Janeiro, Cultura Médica, 1982 p. $9-45$.

26. SETHI, S.K.; KHUFFASH, F.A. \& AL-NAKIB, W. - Microbial etiology of acute gastroenteritis in hospitalized children in Kuwait. Pediat. infect. Dis. J., 8: 593-597, 1989.

27. SHAMEBO, D.; SANDSTRÖM, A.; MUHE, L. et al. - The Butajira project in Ethiopia: a nested case-referent study of under-five mortality and its public health determinants. Bull. Wld. Hlth. Org., 71: 389-396, 1993.

28. SKIRROW, M.B. \& BENJAMIN, J. - Differentiation of enteropathogenic Campylobacter. J. clin. Path., 33: 1122, 1980

29. SMITH, J.W. \& BARLETT, M.S. - Diagnostic parasitology: introduction and methods In: LENNETTE, E.H.; BALOWS, A.; HAUSLER, W.J. \& SHADOMY, H.J. Manual of Clinical Microbiology. 4.ed. Washington, American Society for Microbiology, 1985. p. 602-603.

30. TORRES, A.L.; VIARO, T.; KALLAS, M.R.E.; TRABULSI, L.R. \& FAGUNDES NETO, U. - Observações sobre a favela da cidade Leonor, São Paulo. Rev. paul. Med., 109: 273-277, 1991.

31. VALLE, G.R.F.; NAKAHARA, L.K.; KATO, M.M.F. \& IRINO, K. - Observações de uma década (1984-1994) de shigelose em São Paulo. Bol. Inst. Adolfo Lutz, 8: 9$10,1998$.

32. VERGARA, M.; QUIROGA, M.; GRENON, S. et al. - Prospective study of enteropathogens in two communities of Misiones, Argentina. Rev. Inst Med. trop. S. Paulo, 38: 337-347, 1996.

33. WAUTERS, G. - Antigens of Yersinia enterocolitica. In: BOTTONE, E.J. ed. Yersinia enterocolitica. Boca Raton, 1981.

34. YANO, T.; CATANI, C.F.; ARITA, M.; HONDA, T. \& MIWATANI, T. - Purification and partial characterization of hemagglutinating factor (HAF): a possible adhesive factor of the diffuse adherent of Escherichia coli (DAEC). Rev. Inst. Med. trop. S.Paulo, 38: 401-406, 1996

Received: 10 February 2000

Accepted: 27 August 2000 